\title{
Focus
}

\section{Sola Scriptura: een kwestie van gezag}

T.E. van Spanje

N.a.v. Matthew Barrett, God's Word Alone: The Authority of Scripture. What the Reformers Taught ... and Why It Still Matters (The Five Solas Series; Grand Rapids: Zondervan, 2016) 402 p., \$ 28.99 (ISBN 9780310515722).

\section{Waardevolle en integrale studie}

Naar aanleiding van het vijfhonderdjarige bestaan van de Reformatie zijn onder redactie van Matthew Barrett vijf waardevolle studies in The Five Solas Series uitgegeven. ${ }^{1}$ In 2016 verscheen van hemzelf een studie over sola Scriptura. Nu had wijlen Robert Sproul reeds in 2005 een lezenswaardige studie over ditzelfde thema geschreven. ${ }^{2}$ De meerwaarde van Barretts studie is gelegen in het feit dat Barrett (uiteraard) ook meer recente literatuur heeft verwerkt en ook een 'theologie van het Woord' heeft geschreven.

\section{Selectie}

Uiteraard kunnen in dit focusartikel niet alle waardevolle inzichten van God's Word Alone worden besproken, evenmin bedoelt dit focusartikel een samenvatting ervan te zijn. Slechts enkele aspecten van Barretts studie worden genoemd die relevant zijn voor actuele misverstanden en ontsporingen.

1 Matthew Barrett, God's Word Alone: The Authority of Scripture (2016); Stephen Wellum, Christ Alone: The Uniqueness of Jesus as Savior (2017); Carl Trueman, Grace Alone: Salvation as a Gift of God (2017); Thomas Schreiner, Faith Alone: The Doctrine of Justification (2015), en David VanDrunen, God's Glory Alone: The Majestic Heart of Christian Faith and Life (2015). Alle hebben als ondertitel: What the Reformers Taught ... and Why It Still Matters. Zie ook mijn focusartikel in Theologia Reformata 60.2 (2017), 177-184 naar aanleiding van bovenstaande studie van Thomas Schreiner.

2 R.C. Sproul, Scripture Alone: The Evangelical Doctrine, Phillipsburg 2005. 


\section{Definitie}

Barrett geeft een heldere definitie van sola Scriptura: 'Sola Scriptura means that only Scripture, because it is God's inspired Word, is our inerrant, sufficient, and final authority for the church' (23). ${ }^{3}$ Deze aanduiding bedoelt dus het absolute gezag van de Schrift aan te geven: 'The title of this book is God's Word Alone: The Authority of Scripture, which is another way of saying sola Scriptura ... the Bible is all about authority. In fact, sola Scriptura means that the Bible is our chief, supreme, and ultimate authority' (23).

Sola Scriptura acknowledges that there are other important authorities for the Christian, authorities who should be listed to and followed. But Scripture alone is our final authority. It is the authority that rules over and governs all other authorities. It is the authority that has the final say. We could say that while church tradition and church officials play a ministerial role, Scripture alone plays a magisterial role. This means that all other authorities are to be followed only inasmuch as they align with Scripture, submit to Scripture, and are seen as subservient to Scripture, which alone is our supreme authority (23).

Een dergelijke definitie van sola Scriptura is in overeenstemming met de kerkhistorische gegevens uit de tijd van de Reformatie. Het conflict tussen de reformatoren en de toenmalige kerk bestond immers onder meer in het feit dat de paus meende onfeilbare uitspraken ex cathedra te doen (37) - dus uitspraken met absoluut gezag. 'Luther argued that Scripture alone is our inerrant authority from God' (40).

While popes and councils contradict each other, and therefore err, Scripture alone does not err. Scripture, Luther believed, is the norma normans (the norming norm), rather than the norma normata (the determined, ruled, or normed norm) (45).

In zijn conflict met de kerk van Rome heeft Calvijn zich in soortgelijke bewoordingen uitgelaten (65-70).

Sproul had reeds beargumenteerd dat de 'onfeilbaarheid' van de Schrift essentieel is: 'The Reformation principle of sola Scripture involved inerrancy.' ${ }^{4}$ Barrett: 'It's not just the Reformers who saw (and assumed) this connection

3 Cursief in origineel. Tenzij anders blijkt, verwijzen de cijfers tussen haken telkens naar de desbetreffende pagina's van God's Word Alone.

4 Sproul, Scripture Alone, 18. 
between inerrancy and biblical authority. The Reformed tradition at large has followed suit' (290). ${ }^{5}$

De aanduiding sola Scriptura is nog steeds bruikbaar om de exclusiviteit van het absolute gezag van de Schrift aan te geven. ${ }^{6}$

\section{Radicalisering}

Op een goed beargumenteerde manier beschrijft Barrett, dat voor de reformatoren sola Scriptura beslist niet nuda Scriptura impliceerde. (Zie ook het citaat in de vorige paragraaf omtrent het onderscheid tussen 'ministerial' en 'magisterial' gezag).

... sola Scriptura is too easily confused today with nuda Scriptura, the view that we should have 'no creed but the Bible!' Those who sing this mantra believe that creeds, confessions, the voices of tradition, and those who hold ecclesiastical offices carry no authority in the church. But this was not the Reformers' position, nor should it be equated with sola Scriptura (23).

Reformatoren zoals Luther, Zwingli en Calvijn hebben nooit een strikte scheiding tussen Schrift of traditie gemaakt.

The Reformers believed tradition was on their side. As far as the fathers and councils were consistent with Scripture, Luther said, they were to be listened to and obeyed. In fact, the Reformers became very frustrated when certain radicals sought to discard tradition altogether. For the Reformers, sola Scriptura meant the Bible is our final authority, but it did not mean the Bible is our only authority. The more radical elements of the Reformation were not defending and practicing sola Scriptura; they were turning to nuda Scriptura (55).

5 De onfeilbaarheid van de Schrift heeft regelmatig veel theologische vragen opgeroepen, zoals: heeft deze onfeilbaarheid alleen betrekking op de autografen?, en: sluit deze onfeilbaarheid per definitie grammaticale fouten van de bijbelschrijvers uit? Barrett onderschrijft datgene wat de Chicago Statement on Biblical Inerrancy stelt: 'Scripture is inerrant, not in the sense of being absolutely precise by modern standards, but in the sense of making good its claims and achieving that measure of focused truth at which its authors aimed' (270; zie ook 268).

6 Pace Henk van den Belt, 'The Problematic Character of Sola Scriptura', in: Hans Burger et al. (red.), Sola Scriptura: Biblical and Theological Perspectives on Scripture, Authority, and Hermeneutics, Leiden-Boston 2018, 38-55. 
Barrett geeft twee bekende voorbeelden. Thomas Müntzer (ca. 1489-1525) achtte nieuwe openbaringen door de Geest belangrijker dan de geschreven tekst van de Bijbel.

... leading Luther to conclude that Müntzer 'had swallowed the Holy Ghost, feathers and all.' Internal, inward, subjective spiritual experience had taken the place of the historic, objective Scriptures. Müntzer was advocating not sola Scriptura but sola experientia! (57).

Het tweede voorbeeld is Menno Simons (1496-1561) die weigerde zich te beroepen op specifieke kerkelijke uitspraken/confessies (Nicea en Constantinopel) of op de kerkvaders.

Menno's lack of consultation with the fathers becomes painfully obvious when he departed from Nicene and Chalcedonian Christology by arguing that Jesus assumed a celestial humanity. If Menno would have paid attention to the history of doctrine, he would have avoided this heresy. Instead, his ignorance of the past cursed him to repeat it (57-58).

Barrett concludeert: 'The radical reformers, living up to their name, radicalized sola Scriptura' (58).

\section{Het belang van de traditie (confessies)}

Traditie in de betekenis van 'overlevering' (verg. het Latijnse tradëre, 'overdragen' of 'overleveren') is een 'thoroughly biblical idea'.7 Dit blijkt bijvoorbeeld uit het paulinische gebruik van het Griekse paradidoomi ('overleveren', bijv. 1 Kor. 11:23; 15:3) en paradosis ('overlevering', bijv. 1 Kor. 11:2; 2 Thess. 2:15; 3:6; verg. 2 Tim. 1:14). Hetzelfde geldt bijvoorbeeld ook voor Lukas (bijv. Luk. 1:2) en Judas (Jud. 3) (347). Feiten en confessies worden overgeleverd om de gemeente waarheidsgetrouw te informeren en te houden bij de apostolische leer.

Ook voor de reformatoren was de traditio van groot belang. Zij hebben zich ingespannen om aan te tonen dat hun 'nieuwe leer', op de keper beschouwd, helemaal niet zo nieuw was (zie $\$ 4$ ).

Om de Schrift zo nauwgezet mogelijk te interpreteren dient er ook te worden geluisterd naar confessionele stemmen vanuit het verleden. De Schrift is immers niet aan individuen gegeven maar aan de kerk als gemeenschap.

7 Alister E. McGrath, 'Faith and Tradition', in: Gerald R. McDermott (red.), The Oxford Handbook of Evangelical Theology, Oxford 2010, 81-95 [84]. 
In fact, God never meant for us to read and interpret Scripture on our own. This is a caricature of sola Scriptura and looks more like the nuda Scriptura of the radical reformers ... We are to read Scripture in the community of the church, always standing on top of the shoulders of others as opposed to reinventing the wheel each time we approach a passage. Where we are blind, others can see, and it is often necessary to borrow their hermeneutical light (324).

Op deze manier wordt de bewustwording van eventuele leerstellige afwijkingen groter (zie de twee voorbeelden in $\$ 4$ ).

... it should trouble us, to say the least, to find ourselves disagreeing with orthodox creeds that have stood the test of time. Innovation is often the first indication of heresy. This is why the Reformers sought to tie their exegesis all the way back to the patristic tradition, countering Rome's accusations that the Reformers were inventing new doctrines (346).

In dit verband kunnen minimaal twee andere auteurs worden genoemd die langs dezelfde lijnen denken. Volgens Tony Lane is het niet alleen onverstandig om de traditie te negeren ('those who despise tradition often end up reinventing the earliest heresies of church history'), het is ook onmogelijk ('it is simply not possible to jump back to the Bible as if nothing has happened in the intervening millennia'). ${ }^{8}$

Keith Mathison heeft zelfs een overzicht geboden van allerlei problemen als gevolg van nuda Scriptura of solo Scriptura. ${ }^{9}$ Een dergelijke benadering veroorzaakt

a. Schriftuurlijke problemen, zoals het feit dat interpretatie van teksten een buitenkerkelijke aangelegenheid is geworden, terwijl volgens de Schrift een dergelijke interpretatie primair binnen de kerk plaatsvindt (zie bijv. Hand. 15:1-29);10

b. hermeneutische problemen, zoals het feit dat de rede en het geweten van de individuele exegeet 'the supreme interpreter' worden. 'Yet this results in nothing more than hermeneutical solipsism';11

8 Anthony N.S. Lane, 'Sola Scriptura? Making Sense of a Post-Reformation Slogan', in: Philip E. Satterthwaite en David F. Wright (red.), A Pathway into the Holy Scripture, Grand Rapids 1994, 297-327 [310].

9 Keith A. Mathison, The Shape of Sola Scriptura, Moskou Idaho 2001, 237-253. De twee aanduidingen nuda Scriptura en solo Scriptura betekenen bij Mathison hetzelfde.

10 'The modern Evangelical doctrine of Scripture essentially destroys the real authority of ministers of the Word and the Church as a whole,' ibid., 245.

11 Ibid., 246. 
c. historische problemen, zoals blijkt uit het feit dat nuda Scriptura nooit de opvatting van de vroege kerk is geweest, evenmin die van de kerk in de middeleeuwen. 'However, most proponents of solo scriptura would not be bothered in the least by this fact because they are not concerned to maintain any continuity with the teaching of the early Church'; 12

d. theologische problemen, zoals het verdwijnen van leerstellige grenzen. 'Each man decides for himself what the essential doctrines of Christianity are, each man creates his own creed from scratch, and concepts such as orthodoxy and heresy become completely obsolete,'13 en

e. praktische problemen, zoals het ontstaan van schisma's. 'When each individual's conscience becomes the final authority for that individual, differences of opinion will occur.' ${ }^{\text {14 }}$

\section{Blijvende actualiteit}

De volledige ondertitel van God's Word Alone luidt: The Authority of Scripture. What the Reformers Taught ... and Why it Still Matters. Datgene wat de reformatoren hebben geleerd omtrent het gezag van de Schrift doet er inderdaad nog steeds toe en dient blijvend onder de aandacht te worden gebracht.

\subsection{Geen gelimiteerde onfeilbaarheid}

Volgens Barrett doet zich vandaag een uniek verschijnsel voor: het zoeken naar een soort 'middenweg' (via media) waarbij enerzijds wel het gezag en de genoegzaamheid van de Bijbel worden onderschreven maar anderzijds niet de onfeilbaarheid ervan - of eventueel slechts een gelimiteerde onfeilbaarheid.

Limited inerrancy advocates maintain that while Scripture may not be perfect in all of its details (especially those of historical or cosmological nature) or in every subject it addresses, it is trustworthy in its main message and thus the Bible remains authoritative and sufficient (287).

Deze gelimiteerde onfeilbaarheid en sola Scriptura zouden zelfs naast elkaar kunnen bestaan (287). De onfeilbaarheid van de Schrift zou zich namelijk beperken tot de geestelijke boodschap ervan ('faith and practice', 122), terwijl andere gegevens van de Schrift zouden staan onder het gezag van bijvoorbeeld de ratio.

12 Ibid., 247.

13 Ibid., 250.

14 Ibid., 251. 'Solo scriptura also undermines the legitimate ecclesiastical authority established by Christ ... [Christ] did not establish a democracy,' ibid., 251-252. 
Uiteraard heeft deze limited inerrancy grote gevolgen voor de scheppingsleer, nogal wat historische data van de Schrift, Jezus' wonderen en opstanding, de eschatologie, enzovoort. Voor deze verschuiving van sola Scriptura naar limited inerrancy kan men zich echter niet beroepen op de Reformatie: '... such a move misrepresents sola Scriptura and the history of the Reformation' (122).

\subsection{Bijbel en natuurwetenschap (geologie)}

Met betrekking tot de verhouding Bijbel-natuurwetenschap is sola Scriptura eveneens van belang.

... today there is the tendency among some Christians to elevate science above Scripture, or at least to a place of equal authority. Science, they would argue, is just as authoritative as Scripture and should be followed in its findings, even if those findings conflict with Scripture. In such a view, Scripture is to be interpreted through the grid of science, not vice versa. Should science and Scripture meet an impasse, Scripture, not science, must be either rejected or reconfigured (364).

De natuurlijke (of algemene) openbaring heeft geen autonome functie (338). Daarom dient de natuurlijke openbaring met de natuurwetenschap aan de bijzondere openbaring van de Bijbel te worden getoetst. Sola Scriptura impliceert dat tekstgegevens in controlerende zin hun gezag behouden, ook al kan de natuurwetenschap uiteraard met vrucht gebruikmaken van werkhypothesen. ${ }^{15}$

\subsection{Verlichting, modernisme en postmodernisme}

Baruch Spinoza (1632-1677) heeft de interpretatie van de Schrift onderworpen aan het oordeel van de ratio. Feitelijk liet ook Spinoza zich leiden door de idee van nuda Scriptura (verg. de radicale hervormers, zie \$4): de Bijbel zou zonder kerkelijk gezag moeten worden geïnterpreteerd (87-88). Een dergelijke dichotomie tussen bijbelwetenschap en kerkelijk gezag/dogma zou overigens later door J.P. Gabler (1753-1826) op een systematische manier worden gepropageerd en is in het nieuwtestamentisch onderzoek nog steeds zeer populair. ${ }^{16}$ Uiteindelijk werd het Nieuwe Testament beschouwd als de neerslag van religieuze ervaringen van de eerste christenen. Friedrich Schleiermacher

15 Jakob van Bruggen, Het kompas van het christendom: Ontstaan en betekenis van een omstreden bijbel, Kampen 2002, 78-79.

16 Zie de invloed van: Heikki Räisänen, Beyond New Testament Theology: A story and a programme, Londen $2000^{2}$. 
(1768-1834) heeft een verwoestende invloed op het gezag van de Schrift gehad. 'Schleiermacher created a Copernican revolution in theology because he took special revelation off the throne of authority and replaced it with man's experience' (93, cursief in origineel). Het kost niet zoveel moeite om de invloed van deze 'vader van de moderne theologie' (93) ook vandaag aan te wijzen.

Het postmodernisme wordt primair gekarakteriseerd door relativisme (131). 'To claim to know the truth, or to possess the only truth, is the deadliest, most arrogant sin in the postmodern universe' (132, cursief in origineel). Een ander kenmerk van het postmodernisme met betrekking tot de interpretatie van de Schrift is het deconstructionisme (132): de betekenis van teksten is niet meer afhankelijk van de auteur maar wordt gevormd door de lezer met als gevolg dat teksten net zoveel betekenissen kunnen hebben als er lezers zijn.

No objective, fixed, inherent meaning exists in the text. When this mind-set is applied to the text of Scripture, the Bible becomes a tool for our own agendas ... No objective clarity exists, only a plurality of equally valid, even contradictory, interpretations (303).

Het gevolg is een absoluut hermeneutisch nihilisme en agnosticisme: het exegetisch onderzoek naar de original meaning van een tekst is niet (meer) relevant enzovoort.

Het rationalistische modernisme en het subjectivistische postmodernisme staan haaks op sola Scriptura, zo betoogt Barrett voortdurend: de ratio en de eigen waarheid/ervaring hebben het absolute gezag van de Schrift verdrongen. Het postmodernisme blijkt aan te sluiten bij het sola experientia van de radicale hervormers, zoals Müntzer (zie $\$ 4$ ). Het is dus verklaarbaar dat een theologie die zich laat beïnvloeden door het postmodernisme een bondgenoot vindt in radicale hervormers met hun nuda Scriptura.

\section{Afsluiting}

Uiteraard zouden hier nog veel andere actuele opmerkingen kunnen worden gemaakt, zoals: het belang van sola Scriptura voor de canongeschiedenis (bijv. 352-363) en de huidige tendens om, binnen de christelijke ethiek, de ervaring en de cultuur boven het gezag van de Schrift te plaatsen (366-370). In hoeverre wordt ook een ambtsvisie afhankelijk gemaakt van maatschappelijke tendensen? In het postmodernistische leefklimaat bestaat er een aversie tegen iedere vorm van gezag: nuda Scriptura is aantrekkelijk, omdat het gezag van de confessies wordt opgeschort. Zal daarna ook het absolute gezag van de Schrift het moeten ontgelden? De nalatenschap van de reformatoren houdt ons alert. 